\title{
Co-op education and the impact on the behaviors and competencies of undergraduate engineering students
}

\section{Dr. Nassif E Rayess, University of Detroit Mercy}

Nassif Rayess is Professor and Chair of Mechanical Engineering at University of Detroit Mercy. He was part of the efforts to introduce entrepreneurially minded learning to the University as part of the KEEN Network and Engineering Unleashed. He is also directly involved in the curricular elements of the coop program at the University, and teaches the professional development courses that bookends the co-op semesters. He received his Ph.D. from Wayne State University and joined Detroit Mercy in 2001.

\section{Dr. David Pistrui Dr., University of Detroit Mercy}

David Pistrui, Ph.D., is an executive, entrepreneur, and educator with over 30 years of experience serving the corporate, nonprofit, and education sectors. In 1993, David founded Acumen Dynamics, LLC, a global advisory firm that serves the public and private sectors.

David has held faculty appointments at University of Detroit Mercy, Fayetteville State University, and Illinois Institute of Technology, He has co-authored over 60 publications in the areas of growth strategies, family business, and engineering.

David has held corporate leadership positions with VideoCart, MediaOne, Parade Publications, Time Inc., and Purex Industries. He has worked with a wide range of organizations including Tenneco, KPMG, Motorola, Wrigley, IBM, Comarch, GrubHub, Minnetronix, Cleversafe, Siemans, and Dentsu, among many others.

David holds a Ph.D. (Cum Laude) in Applied Economics, Entrepreneurship and Strategy, from Universitat Autonoma de Barcelona, a Ph.D., in Sociology from the University of Bucharest, a Master of Arts in Liberal Studies from DePaul University, and a Bachelor of Business Administration, in Marketing and Economics from Western Michigan University.

\section{Dr. Ron Bonnstetter, Target Training International}

Dr. Ron Bonnstetter serves as the senior vice president of research and development for Target Training International. With a bachelor's from Mankato State University, master's and doctorate degrees from the University of Iowa and decades of award-winning teaching and research at the University of Nebraska Lincoln, Bonnstetter has amassed an arsenal of recognition and research, including the first recipient of the National Senior Outstanding Science Educator of the Year Award and the only secondary science preparation program recognized in the national Search for Excellence in Science Education. Dr. Bonnstetter was honored with the 2019-2020 Joe Kamiya First-Person Science Award during the annual conference of the International Society of Neurofeedback and Research (ISNR). The award is named in honor of Dr. Joe Kamiya who was the first to document the ability to noninvasively alter brain wave activity by using a simple reward system and is considered the father of modern neurofeedback.

\section{Dr. Eric T Gehrig, Target Training International, Ltd.}

Dr. Eric Gehrig is currently Vice President of Research and Development for Target Training International, Ltd. Dr. Gehrig's educational background includes bachelor's, master's, and doctorate degrees in pure mathematics from Arizona State University. Since 2003, Dr. Gehrig has held various consulting and research roles in areas of supply chain management, banking, finance, economic modeling, and psychometric assessment research and development. 


\section{Co-op education and the impact on the behaviors and competencies of undergraduate engineering students}

\section{Introduction}

Undergraduate engineering education has traditionally, and rightfully, been focused on a mix of technical learning outcomes, complemented by non-technical enablers of professional success (e.g. communication skills and life-long learning). In addition, programs have added learning outcomes that draw on their traditions (e.g. social justice) or on newfound pedagogical theories (e.g. entrepreneurially minded learning). In order to satisfy all these learning outcomes in the span of a four-year curriculum, the engineering curriculum subjects students to a level of rigor and pace that invariably influences their personalities and psyches. Adding to the mix is that many programs have a required co-op rotation that adds an entire range of influences, many of which are unforeseen and out of the control of the engineering programs.

Co-op education has been shown to have numerous effects on students. Co-op education has been shown to have an academic effect, with co-op students getting higher grades in some courses, particularly in those based on soft skills [1]. Co-op education has also been shown to help in self-efficacy, particularly in work-related activities and has also shown to have a positive effect on retention [2]. Co-op education has also been shown to have a positive effect on starting salaries (nearly 10\%) [3]. The goal of this study is to gauge the effect of the co-op employment on the students' behavioral traits and competencies and, in particular as it relates to employer behavior and work conditions. On that front, research shows that socialization, mentorship as well as a positive and nurturing work environment have a quantifiable effect on student wellbeing and development [4].

The engineering curriculum at University of Detroit Mercy is designed to direct the students toward professional practice very early, requiring three co-op semesters beginning in the summer of their freshman year. The likelihood of professional success and, more importantly, the level of satisfaction derived from a professional career are due, in no small part, to self-knowledge and to the use of that knowledge to place oneself to operate from a position of strength [5]. In helping students discover their strengths and weaknesses, the investigators discovered that many students experienced significant changes measured between the first and third year of the engineering curriculum. This paper aims to shed light on the changes in the students' behavioral traits and competencies as they matriculate through the curriculum and engage in co-op and, to relate these changes to the conditions experienced at work.

The instrument

For data collection, TTI's TriMetrix ${ }^{\circledR}$ DNA assessment suite (www.ttisi.com) was used. The TTI TriMetrix® DNA assessment suite (TTI Survey) is comprised of three self-reporting assessment instruments that are administered via an online portal. It is designed to increase the understanding of an individual's talents and abilities in three distinct areas: competencies, motivators and behavioral traits, see Figure 1. 
Along with a narrative description of characteristics and "do's and don'ts" coaching, the TTI survey provides a ranking of the twelve behavioral traits given in Table 1 of the Appendix. There are also twenty-five competencies determined and ranked by the TTI survey. The competencies along with descriptions are given in Table 2 of the Appendix. The motivators in the TTI survey are not discussed in this paper.

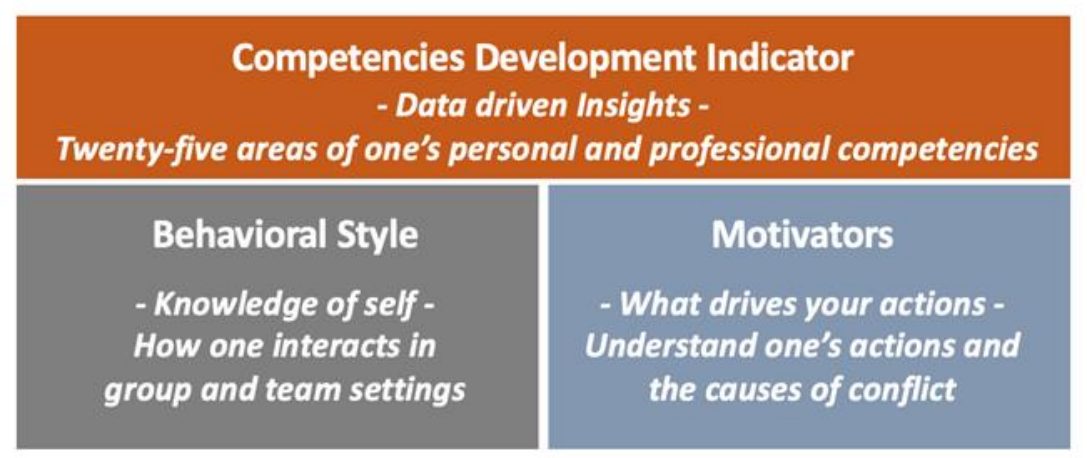

Figure 1 - TTI TriMetrix DNA Assessment Suite - Competencies, Behavioral Style and Motivators

The TTI survey has been used to identify traits and competencies that are believed to be associated with entrepreneurial mindset $[6,7]$ and to guide engineering education towards producing graduates with said mindset [8].

The choice of using the TTI survey for this study was based on the needs of the co-op program at University of Detroit Mercy in relation to its mission to help students succeed in their nascent professional engineering careers. Engineering students at the University are required to have three one-semester long co-ops as a graduation requirement and must seek a co-op at the end of the freshman year. The TTI Survey is designed to help students get a better understanding of themselves, thus making them better prepared to communicate effectively with prospective employers during the job search and interviews. The TTI survey is administered at the beginning of freshman year in order to help students answer basic questions that should be expected in employment screening and interviews, questions such as "tell me about yourself" and "what are some of your strengths and weaknesses?"

The TTI survey is also administered following the second of three co-op semesters around the time when engineering students are at a stage where they would benefit from early career coaching, primarily focused on working from their strengths and managing their professional relationships.

Process and method

The TTI Survey was first administered to incoming freshmen students (within four weeks of entering college) and then again at the beginning of junior year after the students have completed two co-op rotations (a minimum of one is required). In total, the TTI survey was administered to 148 freshman students and 103 junior students between the fall semester of 2017 and the fall semester of 2019. This number accounts for the total engineering students in all three years. The 
survey was first administered as an assignment in the Introduction to Co-op course (students receive a pass/fail grade in the course) which is a required one-credit, lecture-based co-op preparatory course in the first semester. A participation grade was given to students who took the survey in order to encourage participation, but the grade was designed to be inconsequential in order to minimize the possibility of freshmen students taking such an intimate survey under duress. Regardless, the survey participation for freshmen students who competed the course was $98 \%$.

The TTI survey was administered again in the junior year in the context of Professional Practice of Engineering, which is a required lecture-based course that students take after completion of a minimum of one co-op semester. The survey was required and was used in a significant assignment in which students reflect on their strengths and weaknesses and on how to leverage the former and mitigate the latter. The survey participation for junior students who completed the course was $100 \%$.

In order to compensate for the change in the student make-up, a pairwise longitudinal comparison was conducted on the twenty engineering students (14 males and 6 females with 5 being underrepresented minorities) that took the survey as freshmen in Fall 2017 and then again as juniors in Fall 2019. This number of students should have been close to forty. This drop is due mainly to three factors: some students left the program; some could not secure the necessary co-ops; and, others elected to take the Professional Practice of Engineering course in the senior year owing to scheduling problems among other reasons.

The absence of a control group makes it difficult to discern the effect of the co-op program as all engineering students at the University are required to have a minimum of one co-op prior to taking the junior course in which the assessment is administered. To compensate, a basic analysis was conducted on the co-op reflection essays of the twenty students in the pairwise comparison in order to partially remedy the shortcoming of not having a control group and to distinguish the effect of the co-op curriculum from the natural growth and personal refinement that invariably happen between the ages of 19 and 21, corresponding to the average age of freshmen and junior students, respectively.

Results and discussions of behavioral traits

The averaged behavioral traits (described in Appendix Table 1) recorded in this study are shown in Figure 2 for: the freshman engineering students in fall 2017-19; the junior engineering students in fall 2017-2019; the 20-student freshman sample from 2017; and, the same 20-student sample in their junior year, 2019. The aggregate data, shown for illustrative purposes, sheds light on the make-up of the engineering students. On average, engineering students exhibit higher traits relating to: maintaining order in daily activities (organized workplace); analyzing information (analysis); performing in repetitive situations (consistent); finishing tasks despite challenges (persistence); and, adhering to rules and existing methods (following policy). On the other side, the lowest averaged behavioral traits were: taking immediate action (urgency); having the propensity to engage and communicate with others (interaction); wanting to win 
(competitive); adapting easily to changing situations (versatile); and, shifting easily between tasks (frequent change).

Figure 2 reveals some differences between the total population of freshmen and junior engineering students (left of figure) and the twenty-student sample (right of figure). This difference is due to sample size as the spread in students' behavioral traits is significant. A histogram of the "urgency" trait, shown in Figure 3 reveals that while a majority of students cluster around the mean, there are numerous outliers that are near the maximum. Urgency is defined as the propensity to "take immediate action."
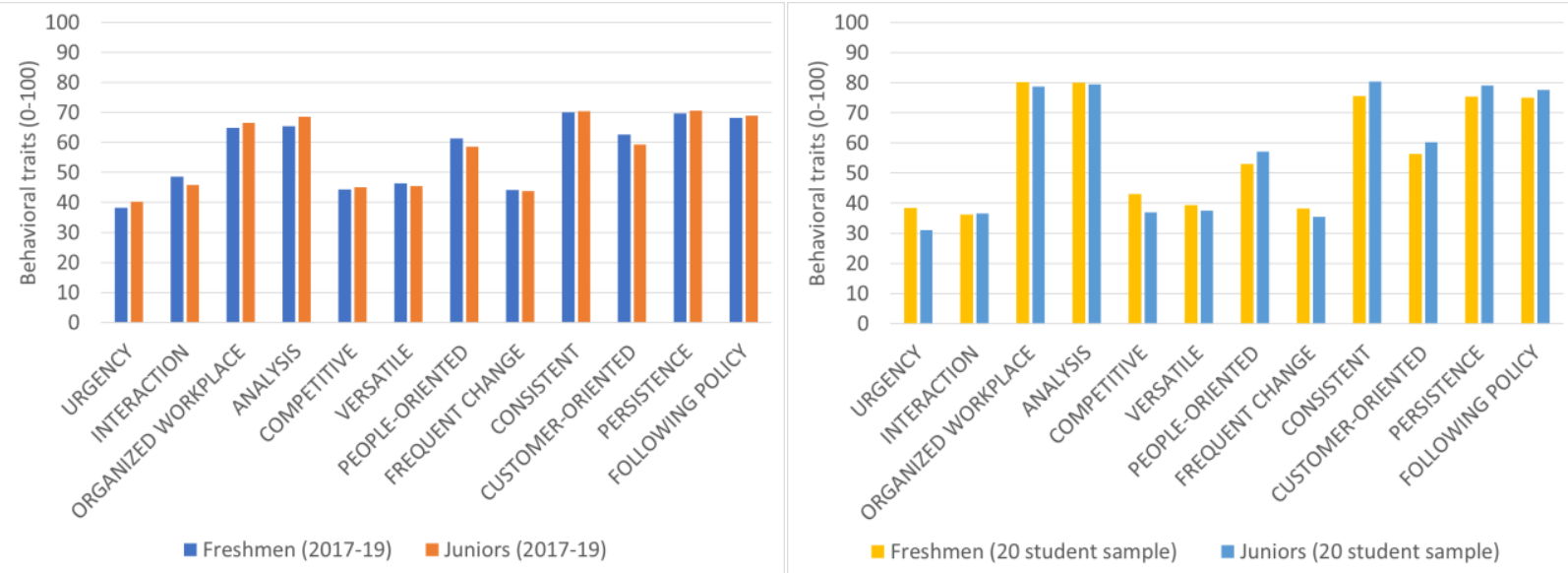

Figure 2 - Mean behavioral traits for the total student population (left) and the twenty-student sample (right).
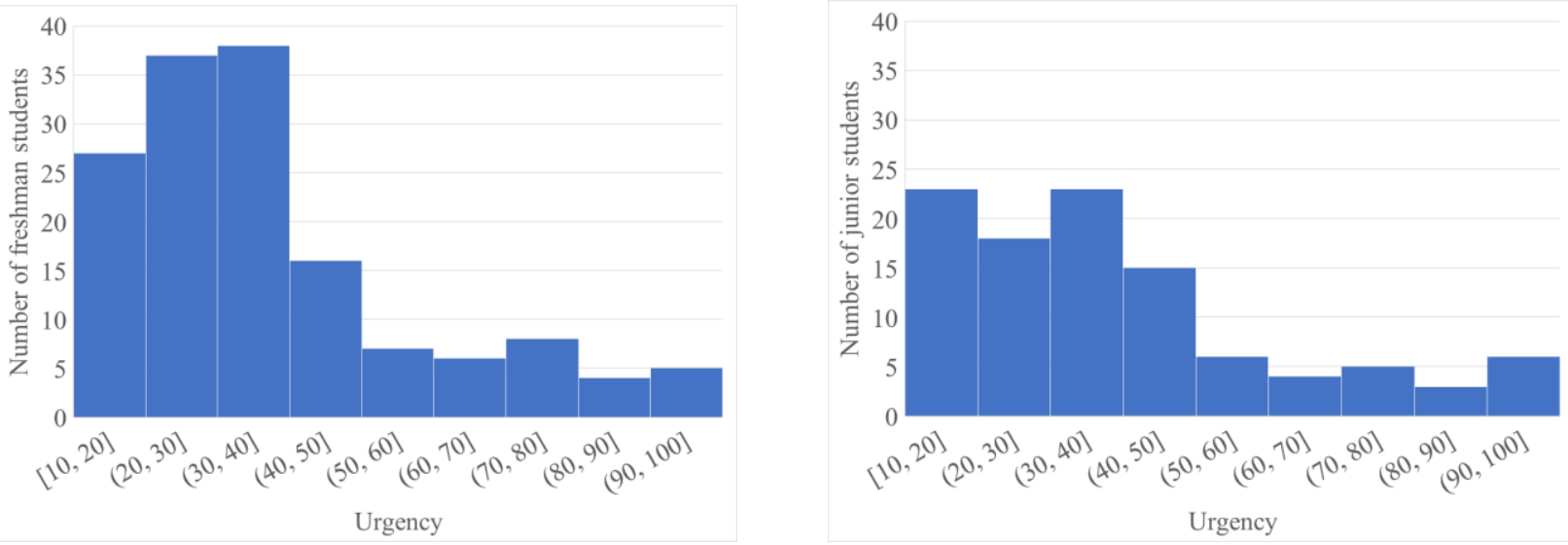

Figure 3 - Histograms of the "urgency" trait (freshmen on the left and juniors on the right) The behavioral traits data is very useful in helping students understand themselves and to help the engineering programs mentor their students. An example of how such information can be used is illustrated in Figure 4 (left) which shows the inverse relationship that exists between the "organized workspace" trait (establish and maintain specific order in daily activities) and the 
"frequent change" trait (rapidly shift between tasks). It stands to reason that the student at the top left potion of the graph and the one at the bottom right will not be suited for the same type of work and this information can be used in guiding engineering students towards the type of employment that best suits them. For example, a student who has a propensity or the need to maintain order in daily activities will fare better in a structured environment such as a quality control job than one who thrives on shifting between tasks while having a fluid working environment.

The change experienced along the "organized workspace" vs. "frequent change" by the 20student sample between freshman and junior year is shown in Figure 4 (right). The arrows indicate the direction of the change. With few exceptions shown in solid red lines, the majority of the students moved along the principal axis (inverse relationship) with most showing significant change, albeit in either direction. There was no discernible correlation between these changes and anything that the students reported to have experienced in co-op, with the factors considered being: type or size of company; industry; and, student experiences while on co-op (e.g. conflict or whether the job entailed office, factory or field work).
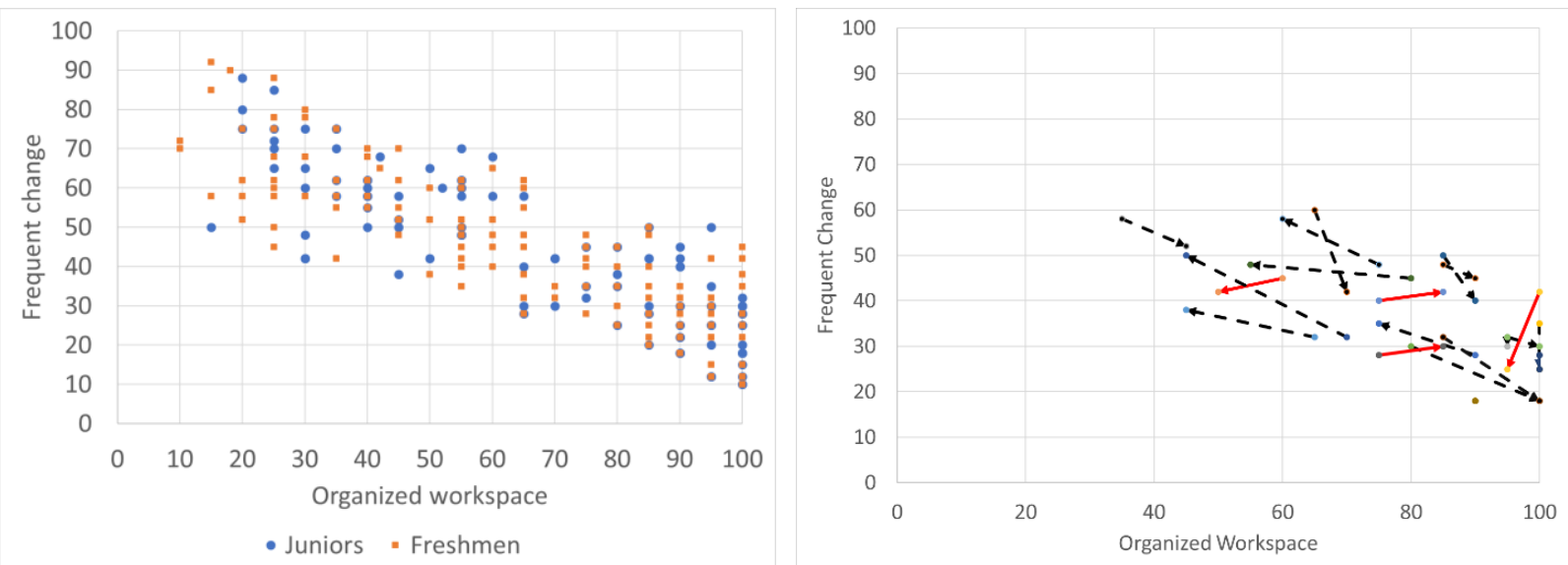

Figure 4 - (left) "frequent change" vs. "organized workspace" - (right) change between freshman and junior year for the 20-student sample

A similar analysis was conducted on the personality traits of "interaction" (frequently engage and communicate with others) and "people oriented" (build rapport with a wide range of individuals) and the results are shown in Figure 5 (left). Predictably, the figure reveals a positive correlation between the two traits. This information can also be useful in mentoring students as they seek co-op employment. A job that requires frequent interaction with others such as manufacturing support during a product launch will be a better choice for someone on the top-right of the figure than for one on the bottom left.

Figure 5 (right) shows the changes experienced by the 20-student sample and again reveals significant changes albeit along the principal axis and in either direction. As in the prior comparison, the authors could not determine any correlation between these changes and the coop experiences of the students. 
The lack of an obvious relationship between the changes in behavioral traits and the co-op experiences of the students while on co-op is not unexpected. An engineering student entering college experiences a wide range of influences, ranging from living independently from the parents, to dealing with the rigor and demand of the college curriculum as well as the early foray into professional work as a co-op student. Thus, it is exceedingly difficult to separate these influences. Moreover, one cannot discount the possibility that the changes between the freshman and junior years could be due in part to the students learning more about themselves.
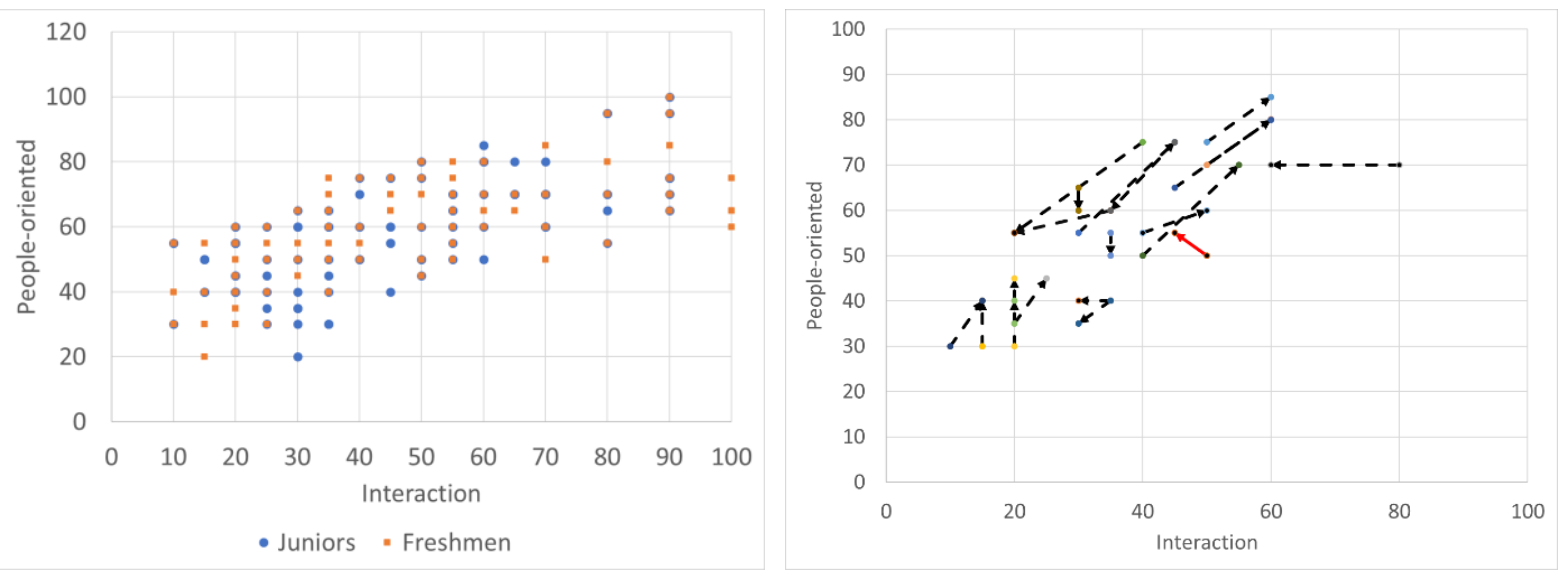

Figure 5 - (left) "interaction" vs. "people-oriented" - (right) change between freshman and junior year for the 20-student sample

\section{Results and discussions of competencies}

The study of the changes in student competencies between the freshman and junior years is more revealing. Competencies can be coached and developed in a far shorter time frame than would be required to effect permanent behavioral changes. For example, taking on realistic projects where innovation is a stated goal and learning specific techniques for structured innovation will likely lead to a marked increase in the "creativity and innovation" competency (creating new approaches, designs, processes, technologies and/or systems to achieve the desired result).

Unlike the case of the behavioral traits which can change in either direction due to everyday influences, it is reasonable to assume that, after two years in an engineering program along with nearly eight months of professional practice, competencies should increase. However, this was not entirely the case. Of the 25 competencies measured by the TTI survey (described in Table 2 of the Appendix), four have shown a decrease for the 20-student sample. Figure 6 (left) shows that the four competencies with the decrease were "appreciating others," "conflict management," "goal orientation," and "interpersonal skills." This poses a disturbing question that invites a closer investigation. One would be remiss for not observing that four other competencies showed large increases, shown in Figure 6 (right). These were "conceptual thinking," "decision 
making," "futuristic thinking" and "self-starting." As these could be considered hallmarks of engineering education, this increase is welcome news.

In order to better understand the reduction in competencies, a comparison was done using the student reports that are graded curricular elements of the co-op program. As part of every final report submitted at the end of the co-op semester, students are asked to reflect on the following question:

"Please describe a conflict that you experienced during the course of your job and reflect on how you handled it. Please be cognizant not to divulge privileged information and not to disparage any person by name."

After anonymizing the responses, a small group of faculty read the responses and provided a measure called "conflict level" scored on a 0-4 scale with zero (0) being "no discernible conflict," two (2) being "normal conflicts that one can expect in a professional setting" and four (4) being "extraordinary no-win conflicts." Table 3 of the Appendix shows the results of this analysis.

Figure 7 shows each of the four reduced competencies plotted against the "conflict level" for all 20 students in the sample. The figure reveals a statistical correlation $\left(R^{2}=0.603\right)$ between the reduction in the "conflict management" competency and the "conflict level." There was a minimal statistical correlation between the change in "interpersonal skills" and "conflict level" $\left(\mathrm{R}^{2}=0.170\right)$. There was no statistical correlation between the "conflict level" and "appreciating others" $\left(\mathrm{R}^{2}=0.016\right)$ as well as "goal orientation" $\left(\mathrm{R}^{2}=0.008\right)$.

The engineering students in the sample has expressed the greatest overall reduction in the "goal orientation" competency defined by "setting, pursuing and attaining goals, regardless of obstacles or circumstances" with nearly half of them decreasing by over $25 \%$ (see bottom right graph in Figure 7). This reduction is problematic given that setting and achieving goals are heavily weighted in performance evaluations of engineering employees. As such, this particular competency will be the focus of future work.
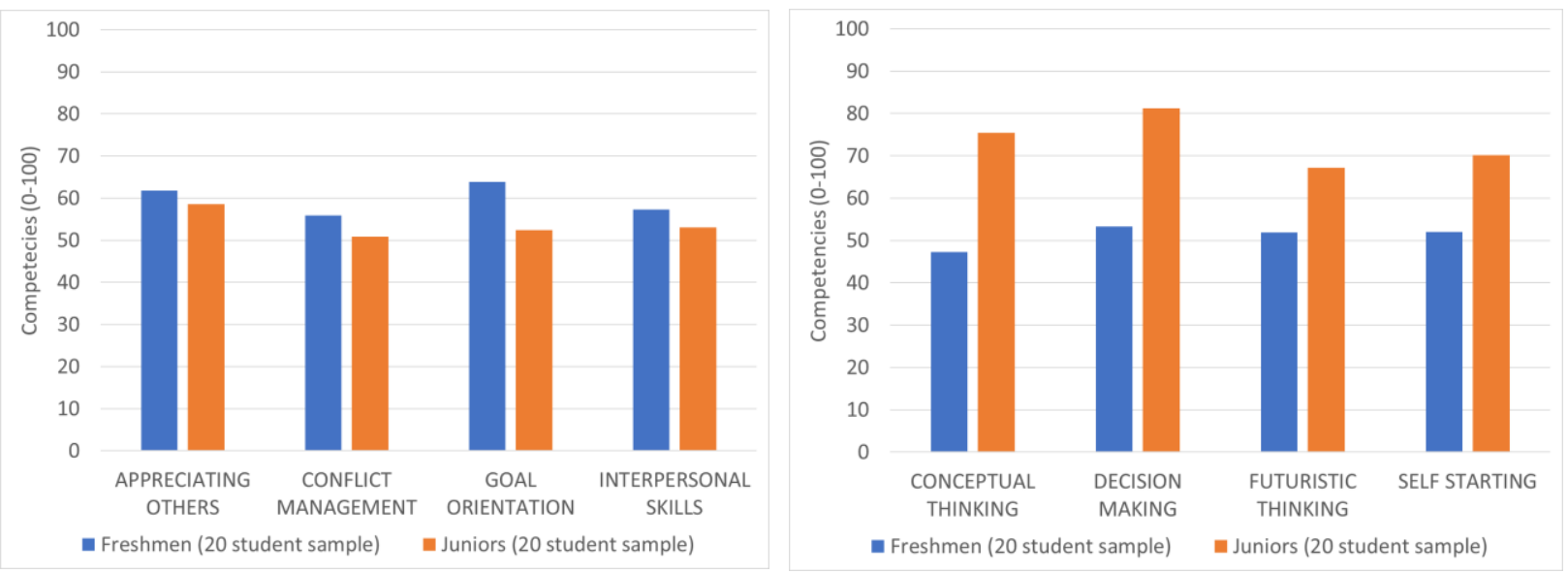

Figure 6-Mean of the TTI competencies 

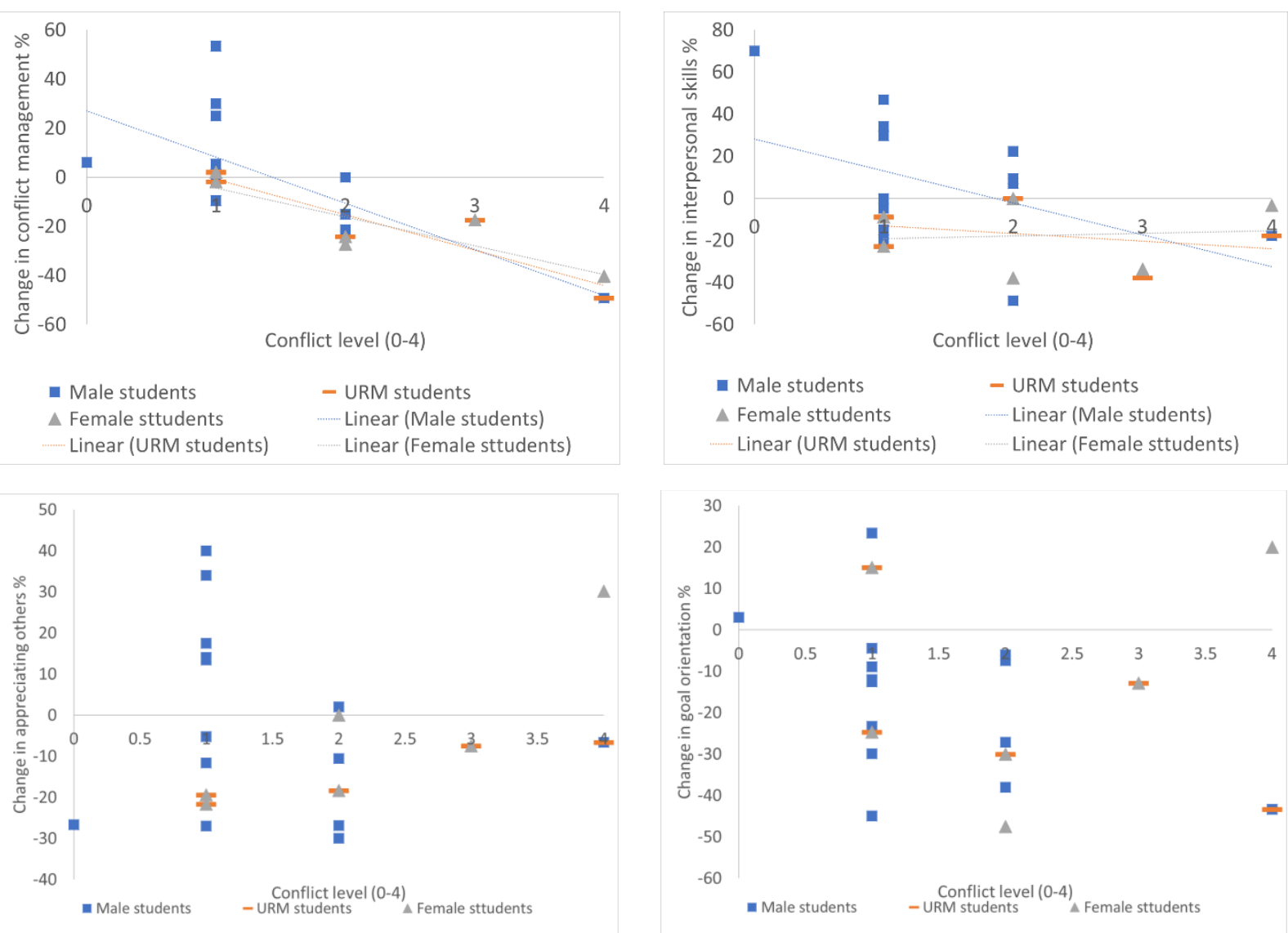

Figure 7 - Decreased competencies plotted against the conflict levels experienced on co-op

\section{Conclusions}

This paper presented the early results of a study to measure the transformation of engineering students as they matriculate through the curriculum at the University, which has a required co-op program consisting of a three semester-long co-op rotation. For data collection, TTI's TriMetrix ${ }^{\circledR}$ DNA assessment suite was used. The TTI survey is designed to increase the understanding of an individual's talents in three distinct areas: competencies, driving forces and behavioral traits. The survey was first administered to incoming freshmen students (within four weeks of entering college) and then again at the beginning of junior year after the students have completed two co-op rotations. A pairwise longitudinal comparison was conducted on twenty engineering students ( 14 males and 6 females with 5 of the students being from underrepresented minorities) that took the survey as freshmen in Fall 2017 and then again as juniors in Fall 2019.

The study revealed significant changes in the behavioral traits of the individuals in the 20 -student sample, but the changes did not exhibit discernable patterns and could not be reliably correlated with elements of the co-op experience. Regardless, the observed behavioral traits have proven valuable in mentoring students and directing them towards the type of work that they are best suited for. 
As for the changes in competencies ( 25 competencies in total), there was a marked increase in fifteen competencies (over 10\%) including a very large increase (over 25\%) in four competencies: conceptual thinking; decision making; futuristic thinking; and, self-starting. There was also a decrease in four competencies: appreciating others; conflict management; goal orientation; and, interpersonal skills. After correlating these changes with the co-op reflection essays of the twenty students, a statistical correlation was found between the decrease in the "conflict management" competency and the severity of conflicts reported by the students during co-op. This finding raises the possibility that impressionable engineering students could be susceptible when faced with difficult conflicts while on co-op. Additional measures such as engaging co-op employers on the subject and monitoring the well-being of the students while on co-op are needed. There was little or no correlation between the severity of conflict and the other three decreased competencies.

Although this research provides some insights, they are only preliminary. There is a need to extend this effort and expand the research. Developing a larger data set will prove valuable to all stakeholders, especially students who can use the knowledge for personal and professional development. The findings indicate that engineering educators together with industry leaders need to take a thorough look and evaluation of current co-op practices, including how company culture and traditions are impacting student development pre and post experience. Extended research presents the opportunity for engineering educators to partner with social scientists, students and industry to continue to gain data driven insights that can be used to improve co-op education and strengthen the talent pipeline.

\section{References}

1. Noyes, C. R., Gordon, J. and Ludlum, J. (2011). The Academic Effects of Cooperative Education Experiences: Does Co-Op Make a Difference in Engineering Coursework? American Society for Engineering Education.

2. Reisberg, R. et.al. (2012). The Effect of Cooperative Education on The Self-Efficacy of Students in Undergraduate Engineering. American Society for Engineering Education.

3. Blair, B. F. and Millea, M. and Hammer, J. (2004). The Impact of Cooperative Education on Academic Performance and Compensation of Engineering Majors. Journal of Engineering Education, 93(4), 333-338.

4. Parsons, C.K., Caylor, E. and Simmons, H.S. (2005). Cooperative Education Work Assignments: The Role of Organizational and Individual Factors in Enhancing ABET Competencies and Co-op Workplace Well-Being. Journal of Engineering Education, 94(3), 309-318.

5. Drucker, P. (2004). Managing Oneself. Harvard Business School Publishing Corporation.

6. Pistrui, D., Layer, J. and Dietrich, S. (2013). Mapping the Behaviors, Motives and Professional Competencies of Entrepreneurially Minded Engineers in Theory and Practice: An Empirical Investigation. The Journal of Engineering Entrepreneurship, ASEE Special Issue, Vol. 4, No. 1, pp. 39-54.

7. Dietrich, S. (2012). A Critical Examination of the Construct Validity of the TTI Performance DNA Survey for the Purpose of Differentiating the Entrepreneurially-Minded 
Engineer. Doctoral Dissertation, College of Technology, Eastern Michigan University, Ypsilanti, MI.

8. Pistrui, D., Bonnstetter, R., Bonnstetter, B. and Fry, C. (2011). Creating, Educating and Assessing a New Class of Entrepreneurial Minded Engineers. The Journal of Engineering Entrepreneurship, Vol. 2, No 2, Special Issue, pp. 1-14.

Appendices

Table 1 - Behavioral traits analyzed by the TTI TriMetrix ${ }^{\circledR}$ DNA assessment suite

\begin{tabular}{|l|l|}
\hline Behavioral trait & Description \\
\hline Urgency & Take immediate action \\
\hline Interaction & Frequently engage and communicate with others \\
\hline Organized workplace & Establish and maintain specific order in daily activities \\
\hline Analysis & Compile, confirm and organize information \\
\hline Competitive & Want to win or gain an advantage \\
\hline Versatile & Adapt to various situations with ease \\
\hline People-oriented & Build rapport with a wide range of individuals \\
\hline Frequent change & Rapidly shift between tasks \\
\hline Consistent & Perform predictably in repetitive situations \\
\hline Customer-oriented & Identify and fulfill customer expectations \\
\hline Persistence & Finish tasks despite challenges or resistance \\
\hline Following policy & Adhere to rules, regulations, or existing methods \\
\hline
\end{tabular}

Table 2 - Competencies determined by the TTI TriMetrix ${ }^{\circledR}$ DNA assessment suite

\begin{tabular}{|l|l|}
\hline Competency & Description \\
\hline Appreciating others & Identifying with and caring about others \\
\hline Conceptual thinking & $\begin{array}{l}\text { Analyzing hypothetical situations, patterns and/or abstract } \\
\text { concepts to formulate connections and new insights }\end{array}$ \\
\hline Conflict management & Understanding, addressing and resolving conflict constructively \\
\hline Continuous learning & $\begin{array}{l}\text { Taking initiative to regularly learn new concepts, technologies } \\
\text { and/or methods }\end{array}$ \\
\hline Creativity and innovation & $\begin{array}{l}\text { Creating new approaches, designs, processes, technologies and/or } \\
\text { systems to achieve the desired result }\end{array}$ \\
\hline Customer focus & $\begin{array}{l}\text { Anticipating, meeting and/or exceeding customer needs, wants } \\
\text { and expectations }\end{array}$ \\
\hline Decision making & $\begin{array}{l}\text { Analyzing all aspects of a situation to make consistently sound } \\
\text { and timely decisions }\end{array}$ \\
\hline Diplomacy & Effectively and tactfully handling difficult or sensitive issues \\
\hline $\begin{array}{l}\text { Employee } \\
\text { development/coaching }\end{array}$ & $\begin{array}{l}\text { Facilitating, supporting and contributing to the professional } \\
\text { growth of others }\end{array}$ \\
\hline Flexibility & $\begin{array}{l}\text { Readily modifying, responding and adapting to change with } \\
\text { minimal resistance }\end{array}$ \\
\hline Futuristic thinking & $\begin{array}{l}\text { Imagining, envisioning, projecting and/or creating what has not } \\
\text { yet been actualized }\end{array}$ \\
\hline
\end{tabular}




\begin{tabular}{|l|l|}
\hline Goal orientation & $\begin{array}{l}\text { Setting, pursuing and attaining goals, regardless of obstacles or } \\
\text { circumstances }\end{array}$ \\
\hline Influencing others & $\begin{array}{l}\text { Personally affecting others actions, decisions, opinions or } \\
\text { thinking }\end{array}$ \\
\hline Interpersonal skills & $\begin{array}{l}\text { Effectively communicating, building rapport and relating well to } \\
\text { all kinds of people }\end{array}$ \\
\hline Leadership & $\begin{array}{l}\text { Organizing and influencing people to believe in a vision while } \\
\text { creating a sense of purpose and direction }\end{array}$ \\
\hline Negotiation & $\begin{array}{l}\text { Listening to many points of view and facilitating agreements } \\
\text { between two or more parties }\end{array}$ \\
\hline Personal accountability & Being answerable for personal actions \\
\hline Planning and organizing & $\begin{array}{l}\text { Establishing courses of action to ensure that work is completed } \\
\text { effectively }\end{array}$ \\
\hline Problem solving & $\begin{array}{l}\text { Defining, analyzing and diagnosing key components of a problem } \\
\text { to formulate a solution }\end{array}$ \\
\hline Project management & $\begin{array}{l}\text { Identifying and overseeing all resources, tasks, systems and } \\
\text { people to obtain results }\end{array}$ \\
\hline Resiliency & Quickly recovering from adversity \\
\hline Self-starting & Demonstrating initiative and willingness to begin working \\
\hline Teamwork & Cooperating with others to meet objectives \\
\hline Time and priority management & $\begin{array}{l}\text { Prioritizing and completing tasks in order to deliver desired } \\
\text { outcomes within allotted time frames }\end{array}$ \\
\hline Understanding others & Understanding the uniqueness and contributions of others \\
\hline & \\
\hline
\end{tabular}

Table 3 - Analysis by student including demographics, changes in competencies and summary of conflict as well as ranking of the conflict on a 0-4 scale with 4 being an extreme conflict

\begin{tabular}{|c|c|c|c|}
\hline Student & Demographic & Change in competencies & Conflict \\
\hline S1 & $\begin{array}{l}\text { Male, } \\
\text { URM }\end{array}$ & $\begin{array}{l}\text { Appreciating others }-1 \% \\
\text { Conflict management } \\
-49 \% \\
\text { Goal orientation }-43 \% \\
\text { Interpersonal skills }-18 \%\end{array}$ & $\begin{array}{l}\text { Company: large automotive } \\
\text { Conflict described: Severe conflict } \\
\text { involving difficult working conditions, } \\
\text { witnessed a co-worker being mistreated } \\
\text { and tried to help } \\
\text { Conflict resolved: No, student avoided } \\
\text { conflict by steering clear of difficult co- } \\
\text { workers } \\
\text { Conflict level (0-4): } 4\end{array}$ \\
\hline S2 & Male & $\begin{array}{l}\text { Appreciating others } \\
+40 \% \\
\text { Conflict management } \\
-1 \% \\
\text { Goal orientation }-30 \% \\
\text { Interpersonal skills }-34 \%\end{array}$ & $\begin{array}{l}\text { Company: small automotive } \\
\text { Conflict described: Mild conflict related } \\
\text { to technical design work } \\
\text { Conflict resolved: Yes } \\
\text { Conflict level }(0-4): 1\end{array}$ \\
\hline S3 & $\begin{array}{l}\text { Female, } \\
\text { URM }\end{array}$ & $\begin{array}{l}\text { Appreciating others - } \\
19 \%\end{array}$ & $\begin{array}{l}\text { Company: mid-size civil engineering } \\
\text { firm }\end{array}$ \\
\hline
\end{tabular}




\begin{tabular}{|c|c|c|c|}
\hline & & $\begin{array}{l}\text { Conflict management } \\
+2 \% \\
\text { Goal orientation }+15 \% \\
\text { Interpersonal skills }-23 \%\end{array}$ & $\begin{array}{l}\text { Conflict described: Mild conflict related } \\
\text { to having little work and dealing with } \\
\text { requesting work } \\
\text { Conflict resolved: Yes } \\
\text { Conflict level (0-4): } 1\end{array}$ \\
\hline S4 & Male & $\begin{array}{l}\text { Appreciating others } \\
-27 \% \\
\text { Conflict management } \\
-2 \% \\
\text { Goal orientation }-23 \% \\
\text { Interpersonal skills }-21 \%\end{array}$ & $\begin{array}{l}\text { Company: mid-size automotive } \\
\text { Conflict described: Mild conflict with a } \\
\text { co-worker and struggling with unfamiliar } \\
\text { work tasks } \\
\text { Conflict resolved: Yes } \\
\text { Conflict level (0-4): } 1\end{array}$ \\
\hline S5 & Male & $\begin{array}{l}\text { Appreciating others } \\
+13 \% \\
\text { Conflict management } \\
+25 \% \\
\text { Goal orientation }-12 \% \\
\text { Interpersonal skills } \\
+47 \%\end{array}$ & $\begin{array}{l}\text { Company: Government, defense } \\
\text { Conflict described: Personal ethical } \\
\text { conflict about the nature of the work } \\
\text { Conflict resolved: No } \\
\text { Conflict level (0-4): } 1\end{array}$ \\
\hline S6 & $\begin{array}{l}\text { Female, } \\
\text { URM }\end{array}$ & $\begin{array}{l}\text { Appreciating others } \\
-22 \% \\
\text { Conflict management } \\
-2 \% \\
\text { Goal orientation }-25 \% \\
\text { Interpersonal skills }-9 \% \\
\end{array}$ & $\begin{array}{l}\text { Company: Small IT firm } \\
\text { Conflict described: Personal internal } \\
\text { conflict about work } \\
\text { Conflict resolved: Yes } \\
\text { Conflict level (0-4): } 1\end{array}$ \\
\hline S7 & Male & $\begin{array}{l}\text { Appreciating others }+2 \% \\
\text { Conflict management } \\
-15 \% \\
\text { Goal orientation }-38 \% \\
\text { Interpersonal skills } \\
+22 \%\end{array}$ & $\begin{array}{l}\text { Company: Large defense } \\
\text { Conflict described: Technical and } \\
\text { scheduling disagreements with manager } \\
\text { and co-workers } \\
\text { Conflict resolved: Yes } \\
\text { Conflict level (0-4): } 2\end{array}$ \\
\hline S8 & Male & $\begin{array}{l}\text { Appreciating others } \\
-30 \% \\
\text { Conflict management } \\
0 \% \\
\text { Goal orientation }-7 \% \\
\text { Interpersonal skills }+7 \%\end{array}$ & $\begin{array}{l}\text { Company: Mid-size civil engineering } \\
\text { firm } \\
\text { Conflict described: Managing contractors } \\
\text { Conflict resolved: Yes } \\
\text { Conflict level (0-4): } 2\end{array}$ \\
\hline S9 & Male & $\begin{array}{l}\text { Appreciating others } \\
-15 \% \\
\text { Conflict management } \\
+5 \% \\
\text { Goal orientation }-12 \% \\
\text { Interpersonal skills }-20 \%\end{array}$ & $\begin{array}{l}\text { Company: Small manufacturing firm } \\
\text { Conflict described: Scheduling conflicts } \\
\text { Conflict resolved: Yes } \\
\text { Conflict level (0-4): } 1\end{array}$ \\
\hline S10 & Male & $\begin{array}{l}\text { Appreciating others } \\
+17 \% \\
\text { Conflict management } \\
+53 \%\end{array}$ & $\begin{array}{l}\text { Company: International exchange } \\
\text { Conflict described: Project and language } \\
\text { difficulties } \\
\text { Conflict resolved: Yes }\end{array}$ \\
\hline
\end{tabular}




\begin{tabular}{|c|c|c|c|}
\hline & & $\begin{array}{l}\text { Goal orientation }-45 \% \\
\text { Interpersonal skills }-15 \%\end{array}$ & Conflict level (0-4): 1 \\
\hline S11 & Female & $\begin{array}{l}\text { Appreciating others } \\
+30 \% \\
\text { Conflict management } \\
-40 \% \\
\text { Goal orientation }+20 \% \\
\text { Interpersonal skills }-4 \%\end{array}$ & $\begin{array}{l}\text { Company: Large defense } \\
\text { Conflict described: Extreme difficulties } \\
\text { with a no-win situation obtaining } \\
\text { required information from suppliers } \\
\text { Conflict resolved: Yes } \\
\text { Conflict level (0-4): } 4\end{array}$ \\
\hline S12 & Male & $\begin{array}{l}\text { Appreciating others }-5 \% \\
\text { Conflict management } \\
-2 \% \\
\text { Goal orientation }-5 \% \\
\text { Interpersonal skills } 0 \%\end{array}$ & $\begin{array}{l}\text { Company: Government, transportation } \\
\text { Conflict described: Work assignment } \\
\text { within team } \\
\text { Conflict resolved: Yes } \\
\text { Conflict level (0-4): } 1\end{array}$ \\
\hline S13 & Male & $\begin{array}{l}\text { Appreciating others } \\
-10 \% \\
\text { Conflict management } \\
-21 \% \\
\text { Goal orientation }-6 \% \\
\text { Interpersonal skills }+9 \%\end{array}$ & $\begin{array}{l}\text { Company: Mid-size automotive } \\
\text { Conflict described: Mild conflict related } \\
\text { to having little work and dealing with } \\
\text { requesting work } \\
\text { Conflict resolved: Yes } \\
\text { Conflict level (0-4): } 2\end{array}$ \\
\hline S14 & Male & $\begin{array}{l}\text { Appreciating others } \\
+34 \% \\
\text { Conflict management } \\
+5 \% \\
\text { Goal orientation }+23 \% \\
\text { Interpersonal skills } \\
+30 \%\end{array}$ & $\begin{array}{l}\text { Company: Large materials supplier } \\
\text { Conflict described: Personal conflict with } \\
\text { technician } \\
\text { Conflict resolved: No, decided to work } \\
\text { with others } \\
\text { Conflict level (0-4): } 1\end{array}$ \\
\hline S15 & Male & $\begin{array}{l}\text { Appreciating others } \\
-27 \% \\
\text { Conflict management } \\
+6 \% \\
\text { Goal orientation }+3 \% \\
\text { Interpersonal skills } \\
+70 \%\end{array}$ & $\begin{array}{l}\text { Company: International exchange } \\
\text { Conflict described: No discernable } \\
\text { conflict } \\
\text { Conflict resolved: Yes } \\
\text { Conflict level }(0-4): 0\end{array}$ \\
\hline S16 & Male & $\begin{array}{l}\text { Appreciating others } \\
+14 \% \\
\text { Conflict management } \\
+30 \% \\
\text { Goal orientation }-9 \% \\
\text { Interpersonal skills }-5 \%\end{array}$ & $\begin{array}{l}\text { Company: Small engineering firm } \\
\text { Conflict described: Design disagreement } \\
\text { with supervisor } \\
\text { Conflict resolved: Yes } \\
\text { Conflict level }(0-4): 1\end{array}$ \\
\hline S17 & $\begin{array}{l}\text { Female, } \\
\text { URM }\end{array}$ & $\begin{array}{l}\text { Appreciating others }-7 \% \\
\text { Conflict management } \\
-18 \% \\
\text { Goal orientation }-13 \% \\
\text { Interpersonal skills }-34 \%\end{array}$ & $\begin{array}{l}\text { Company: International, } \\
\text { telecommunication } \\
\text { Conflict described: Not fitting in in a } \\
\text { male dominated environment } \\
\text { Conflict resolved: Yes } \\
\text { Conflict level }(0-4): 3\end{array}$ \\
\hline S18 & Female & Appreciating others $0 \%$ & Company: Small automotive \\
\hline
\end{tabular}




\begin{tabular}{|c|c|c|c|}
\hline & & $\begin{array}{l}\text { Conflict management } \\
-27 \% \\
\text { Goal orientation }-47 \% \\
\text { Interpersonal skills }-38 \%\end{array}$ & $\begin{array}{l}\text { Conflict described: Difficulty getting } \\
\text { help } \\
\text { Conflict resolved: No } \\
\text { Conflict level (0-4): } 2\end{array}$ \\
\hline S19 & $\begin{array}{l}\text { Female, } \\
\text { URM }\end{array}$ & $\begin{array}{l}\text { Appreciating others } \\
-18 \% \\
\text { Conflict management } \\
-24 \% \\
\text { Goal orientation }-30 \% \\
\text { Interpersonal skills 0\% }\end{array}$ & $\begin{array}{l}\text { Company: Large automation } \\
\text { Conflict described: Difficulty with } \\
\text { technical aspect of job } \\
\text { Conflict resolved: Yes } \\
\text { Conflict level (0-4): } 2\end{array}$ \\
\hline S20 & Male & $\begin{array}{l}\text { Appreciating others } \\
-27 \% \\
\text { Conflict management } \\
-24 \% \\
\text { Goal orientation }-27 \% \\
\text { Interpersonal skills - } 49 \%\end{array}$ & $\begin{array}{l}\text { Company: Mid-size engineering } \\
\text { Conflict described: Difficulty } \\
\text { coordinating with others } \\
\text { Conflict resolved: Yes } \\
\text { Conflict level (0-4): } 2\end{array}$ \\
\hline
\end{tabular}

